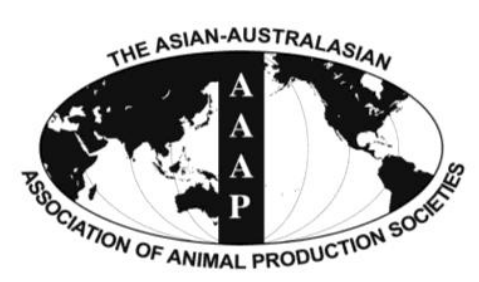

Open Access

Asian Australas. J. Anim. Sci.

Vol. 28, No. 2 : 280-289 February 2015

http://dx.doi.org/10.5713/ajas.14.0312

www.ajas.info

pISSN 1011-2367 elSSN 1976-5517

\title{
Biogas Production from Vietnamese Animal Manure, Plant Residues and Organic Waste: Influence of Biomass Composition on Methane Yield
}

\author{
T. T. T. Cu*, T. X. Nguyen, J. M. Triolo ${ }^{1}$, L. Pedersen ${ }^{1}$, V. D. Le, P. D. Le ${ }^{2}$, and S. G. Sommer ${ }^{1}$ \\ Faculty of Animal Science and Aquaculture, Vietnam National University of Agriculture, \\ Gialam, Hanoi 10000, Vietnam
}

\begin{abstract}
Anaerobic digestion is an efficient and renewable energy technology that can produce biogas from a variety of biomasses such as animal manure, food waste and plant residues. In developing countries this technology is widely used for the production of biogas using local biomasses, but there is little information about the value of these biomasses for energy production. This study was therefore carried out with the objective of estimating the biogas production potential of typical Vietnamese biomasses such as animal manure, slaughterhouse waste and plant residues, and developing a model that relates methane $\left(\mathrm{CH}_{4}\right)$ production to the chemical characteristics of the biomass. The biochemical methane potential (BMP) and biomass characteristics were measured. Results showed that piglet manure produced the highest $\mathrm{CH}_{4}$ yield of 443 normal litter (NL) $\mathrm{CH}_{4} \mathrm{~kg}^{-1}$ volatile solids (VS) compared to 222 from cows, 177 from sows, 172 from rabbits, 169 from goats and 153 from buffaloes. Methane production from duckweed (Spirodela polyrrhiza) was higher than from lawn grass and water spinach at 340,220 , and $110.6 \mathrm{NL} \mathrm{CH}_{4} \mathrm{~kg}^{-1} \mathrm{VS}$, respectively. The BMP experiment also demonstrated that the $\mathrm{CH}_{4}$ production was inhibited with chicken manure, slaughterhouse waste, cassava residue and shoe-making waste. Statistical analysis showed that lipid and lignin are the most significant predictors of BMP. The model was developed from knowledge that the BMP was related to biomass content of lipid, lignin and protein from manure and plant residues as a percentage of VS with coefficient of determination (R-square) at 0.95 .This model was applied to calculate the $\mathrm{CH}_{4}$ yield for a household with 17 fattening pigs in the highlands and lowlands of northern Vietnam. (Key Words: Biochemical Methane Potential, Biogas, Vietnam, Manures, Organic Wastes, Inhibition)
\end{abstract}

\section{INTRODUCTION}

The rapid industrialisation and economic progress in Vietnam in the last decade has led to a significant increase in energy consumption. From 2000 to 2008, natural gas demand increased at a rate of $20.5 \%$ per year (Institute of Energy, 2010) and Vietnam is predicted to increasingly become reliant on the import of fossil fuels. It is recognised that there is a large amount of unused biomass available for

\footnotetext{
* Corresponding Author: T. T. T. Cu. Tel: +84-66747368, Fax: +84-4 38726554, E-mail: cut@kbm.sdu.dk

1 University of Southern Denmark, Faculty of Engineering, Institute of Chemical Engineering, Biotechnology and Environmental Engineering, 5230 Odense M, Denmark.

${ }^{2}$ Hue University of Agriculture and Forestry, Hue City 47000, Vietnam.

Submitted Apr. 16, 2014; Revised Jul. 10, 2014; Accepted Jul. 28, 2014
}

energy production in Vietnam. Biomass resources such as cassava residue, fish waste, animal manure and municipal organic solid waste are deposited or discharged without any concern for the environment (Khanh Toan et al., 2011), but could instead be used for generating energy rather than polluting the environment.

Biogas technology is viewed as a method not only for solving environmental problems, but also for contributing to energy production and resolving economic and social issues (Cu et al., 2012). However, biogas production is normally unstable and out of control in Vietnam due to a lack of knowledge about management of biogas digesters and the usefulness of local feed for biogas production. It is therefore important to provide more information about the biogas production potential of local biomasses.

Currently most biogas digesters in Vietnam are simple, unheated, small household dome digesters. Recent studies 
have shown that farmers add too much slurry to digesters (Cu et al., 2012), partly because they are not aware of the biogas potential of biomass. Overloading leads to surplus biogas being produced, exceeding the household's requirements and unnecessarily releasing greenhouse gases into the environment (Bruun et al., 2014).

Some studies provide information about the relationship between biogas production potential and biomass composition in the industrial sector (Gunaseelan, 1997; Møller et al., 2004; Amon et al., 2007), including Vietnam (Le et al., 2013), but only few studies concern the biogas production potential of typical Asian biomasses and none at all concern the relationship between biogas production potential and the chemical composition of typical Vietnamese biomasses. As a consequence, estimations of the biogas production of household digesters may be incorrect because animal manure composition in Vietnamese biomass may differ from that in industrialised countries due to the use of local feed. Farmers often use agricultural residues available on their farms as a source of feed for their animals.

The objective of this study was therefore to determine the biochemical methane potential (BMP) of relevant Vietnamese biomasses used for biogas production and to develop an equation to estimate BMP from the chemical composition of the biomass being added. The hypothesis was that with a measure of the relationship between biogas production and the chemical composition of the manure, it would be possible to predict and control the amount of $\mathrm{CH}_{4}$ produced. Furthermore, the consequent use of the BMP from this study in biogas production models developed recently by Pham et al. (2014) and Rennuit and Sommer (2013) demonstrates the usefulness of knowing BMP for calculating the monthly methane yield for pig farm biogas digesters in lowland and highland areas in northern Vietnam.

\section{MATERIALS AND METHODS}

\section{Sample collection}

Diverse animal manures from pigs, cows, chickens, goats, rabbits, sheep and buffaloes were collected for this study (Table 1). Slaughterhouse waste consisted of cattle, pig and fish processing waste. Lignocellulosic biomass was made up of plant residues from harvesting water spinach, duckweed and grass. Municipal waste and industrial organic waste consisted of organic household waste, shoe production waste and cassava residues from cassava starch processing.

Piglet and sow manures were collected immediately and separately after excretion from a pig farm in the Van Giang district, Hung Yen province. Cow and buffalo manure samples were collected from the slurry pit on a cattle farm at Hanoi University of Agriculture, and chicken manure was sampled on the premises of the Lac Ve chicken company in Bac Ninh province. Goat, sheep and rabbit manures were collected from the Goat and Rabbit Research Centre in Ba Vi district, Hanoi. Cattle and pig slaughterhouse waste was collected from abattoirs in Hanoi. Slaughterhouse substrates included the rumen, stomach and intestines. Blood and internal organs are retained for human food. Hair and nails were excluded due to their low biodegradability. Fish waste was taken from fish markets in Hanoi and contained mainly fish viscera. Household waste was taken from ten households and separated to ensure that only biowaste was used in the study. Cassava residues were collected from the remains of cassava starch production from a household in Hoai Duc district, Ha Tay province. Waste from shoe production was taken from the Leather and Shoe Research Institute in Hanoi. Inoculum was collected from a pig farm biogas plant $\left(15 \mathrm{~m}^{3}\right)$ in the Van Giang district.

\section{Biochemical characterisation}

The collected biomass samples were analyzed for dry matter (DM), volatile solids (VS), crude protein (CP), crude lipid (CL), cellulose, hemicellulose and lignin contents. The $\mathrm{DM}$ was determined after a 24-hour drying period at $105^{\circ} \mathrm{C}$. The VS was measured as the difference between DM and ash content following incineration of $\mathrm{DM}$ at $550^{\circ} \mathrm{C}$ for three hours. Total Kjeldahl nitrogen content was determined according to the standard method (APHA, 2005) and CP by multiplying the nitrogen content by 6.25 . The $\mathrm{CL}$ was measured by dissolving substrates in diethyl ether according to the Soxleth method. Neutral detergent fibre, acid detergent fibre and acid detergent lignin were measured to determine hemicellulose, cellulose and lignin according to Van Soest's method (Van Soest, 1963) and using the Ankom

Table 1. Feed composition for animals in the study

\begin{tabular}{ll}
\hline Animal manure & \multicolumn{1}{c}{ Feed characteristics } \\
\hline Sheep and goat & Guinea grass and elephant grass+concentrate feed (protein 14\%, fiber10\%) \\
Rabbit & Guinea grass and water spinach+concentrate feed (protein 16\%, fiber 16\%) \\
Cow and buffalo & Natural grazing on pastures \\
Chicken & Feed concentrate with protein $17 \%$ \\
Piglet & Feed concentrate with protein $15 \%$, fiber $10 \%$ \\
Sow & Water spinach, banana tree+feed concentrate (protein 14.7\%, fiber 11\%) \\
Dairy cow & Guinea and elephant grass+feed concentrate (protein 14\%, fiber 10\%) \\
\hline
\end{tabular}


technology protocol (Ankom, 2014).

\section{Biochemical methane potential assay}

The BMP of each sample was determined according to Møller et al. (2004) using batch reactors with a volume of $1.1 \mathrm{~L}$. After adding a known amount of substrate and an active anaerobic inoculum, the bottles were sealed tightly with butyl rubber stoppers and flushed with $\mathrm{N}_{2}$. All assays were performed in triplicate, including three bottles containing only inoculum to account for $\mathrm{CH}_{4}$ production from the inoculum, and three bottles with cellulose were used as a control of the quality of the inoculum. All samples were analyzed for DM and VS before the test and the data used to determine the inoculum substrate ratio, which was set to $1: 1$ based on the VS concentration. All bottles were incubated at a constant mesophilic temperature $\left(37^{\circ} \mathrm{C}\right)$. The volume of biogas produced in each reactor was measured daily using a large syringe during the first month, and once a week thereafter until no further gas was produced. The bottles were shaken manually once a day. After the gas volume had been measured, a $10-\mathrm{mL}$ gas sample was taken and stored in a glass vial until the $\mathrm{CH}_{4}$ content was measured using a gas chromatograph (GC17A Shimazu, Kyoto, Japan), with helium as the carrier gas and at a flow rate of $31 \mathrm{~mL} / \mathrm{min}$. Methane was detected using a flame ionization detector, which was operated at a temperature of $250^{\circ} \mathrm{C}$. The inoculum was incubated for three weeks at $37^{\circ} \mathrm{C}$ before the start of the experiment to reduce the biogas production potential of the inoculum. The BMP is given in normal litters (NL) at $273 \mathrm{~K}, 1.013$ bar (Pham et al., 2013).

\section{Data analysis}

Minitab version 16 software was used for statistical analysis. The BMP prediction was modelled by a stepwise regression test in which a sequential simple linear regression test and a multiple linear regression test were performed. Best subset regression analyses were performed to identify the variables that correlated significantly with measured BMP at $\mathrm{p}<0.05$.

\section{Calculation of methane yield in Hanoi and Sapa}

From the statistical model developed in this study, the BMP value ( $\beta o$ in the Hashimoto equation below) from different types of substrate can be predicted based on their chemical composition. In order to make it easier for farmers to estimate the $\mathrm{CH}_{4}$ volume produced in their biogas digester, the production from a given digester was calculated based on an extended Hashimoto equation. This equation takes into account the difference in lowland and highland temperature regimes, represented by the Hanoi and Sapa cities, respectively. It is assumed that the mean monthly air temperature represents the mean monthly digester temperature (Perrigault et al., 2012).

The original Hashimoto equation (Chen and Hashimoto, 1978; Hashimoto et al., 1981):

$$
\gamma=\frac{\beta_{0} \cdot S_{0}}{H R T}\left(1-\frac{K}{H R T \cdot \mu m-1+K}\right)
$$

where $\gamma$ is the methane yield ( $\mathrm{NL} \mathrm{CH}_{4}$ digester $^{-1}$ day $^{-1}$ ), $\beta_{0}$ is the BMP value of specific substrate $\left(\mathrm{NL} \mathrm{CH}_{4} \mathrm{~kg} \mathrm{VS}^{-1}\right)$, $S_{0}$ is the VS concentration $\left(\mathrm{g} \mathrm{kg}^{-1}\right), H R T$ is the hydraulic retention time (days) and $K$ is the kinetic constant ( $K=$ $\left.0.6+0.0206 \cdot \operatorname{Exp}\left[0.051 \cdot \mathrm{S}_{0}\right]\right), \quad \mu m$ is maximum specific growth rate $\left(\right.$ day $\left.^{-1}\right) . \mu \mathrm{m}=0.013 \mathrm{~T}-0.129$, for temperature $(\mathrm{T})$ between $20^{\circ} \mathrm{C}$ and $60^{\circ} \mathrm{C}$.

The extended Hashimoto equation was applied to calculate the methane yield for a biogas digester following Rennuit and Sommer (2013) for an air temperature from $15^{\circ} \mathrm{C}$ to $30^{\circ} \mathrm{C}$ :

$$
\begin{aligned}
& \gamma_{w \text { inter }}(H R T, \mu m, T d) \\
& =\beta_{0} \times\left[1-\frac{K}{\mu m(T d) \times\left(H R T+\frac{1}{\mu m(T d)}\right)-1+K}\right]
\end{aligned}
$$

and for an air temperature from $20^{\circ} \mathrm{C}$ to $60^{\circ} \mathrm{C}$ :

$$
\begin{aligned}
& \gamma_{\text {summer }}(H R T, \mu m, T d) \\
& =\beta_{0} \times\left[1-\frac{K}{\mu m(T d) \times H R T-1+K}\right]
\end{aligned}
$$

where $\mu m(T d)$ is the maximum specific growth rate of the microorganisms at the digester temperature in the temperature interval from $10^{\circ} \mathrm{C}$ to $30^{\circ} \mathrm{C}(\mu \mathrm{m}[\mathrm{Td}]=0.0039$ $\mathrm{e}^{0.1188 \cdot(\mathrm{Td})}\left(\right.$ day $\left.^{-1}\right)$; Pham et al. (2013) and $(T d)$ is the digester temperature which is set to be equal to the average monthly air temperature $\left({ }^{\circ} \mathrm{C}\right)$ represented by Hanoi and Sapa).

Assuming that a farmer owns 17 fattening pigs and one pig produces $0.86 \mathrm{~kg}$ manure day ${ }^{-1}$ (Vu et al., 2012), the amount of manure per day for 17 pigs is $14.6 \mathrm{~kg}$. Normally in Vietnam the water:manure ratio in the digester is 9:1, therefore $14.6 \mathrm{~kg}$ manure day ${ }^{-1} \cdot 10=146.3 \mathrm{~kg}$ slurry day ${ }^{-1}$. The volume of the most commonly used Vietnamese digester is $7 \mathrm{~m}^{3}$ and the volume of slurry in the digester is $5.6 \mathrm{~m}^{3}$, which leads to a HRT of 38.3 days, according to the daily slurry amount. The air temperature calculation was based on the weather forecast website (http://www.accuweather.com). The production was given as monthly methane outcome $\left(\mathrm{CH}_{4} \mathrm{NL}_{\text {digester }}^{-1}\right.$ month $\left.^{-1}\right)$. 
RESULTS AND DISCUSSIONS

\section{Compositions of the substrate samples}

Of the animal manures, chicken manure had the highest DM content at $37.9 \%$, followed by $37.2 \%$ in sow manure, $35.2 \%$ in goat manure and $32.7 \%$ in rabbit manure. The DM contents for dairy cow, buffalo and piglet manures ranged from $15.9 \%$ to $19.4 \%$ (Table 2). These results show that the DM contents of solid manures in Vietnam are not much different from manures collected in industrial countries
(Sommer et al., 2001; Møller et al., 2004). For slaughterhouse waste, fish waste had the highest DM content at $60 \%$ (and a high lipid concentration of $86 \%$ of DM, which is much higher than in cattle and pig slaughter waste) and shoe waste had the lowest DM content of all substrates at $1.7 \%$.

Of the manures, piglet and chicken manures had the highest protein contents at $24.7 \%$ and $18.3 \%$, respectively. This reflects the higher protein content in commercial feeds for pigs in Vietnam than in other countries such as Denmark

Table 2. Chemical composition of biomass in this study

\begin{tabular}{|c|c|c|c|c|c|c|c|c|c|c|}
\hline $\begin{array}{l}\text { Substrate } \\
\text { groups }\end{array}$ & Substrates & $\mathrm{N}=3$ & $\begin{array}{c}\mathrm{DM} \\
(\% \text { in fresh })\end{array}$ & $\begin{array}{l}\mathrm{VS}^{1} \\
(\%)\end{array}$ & $\begin{array}{c}\text { Protein }^{1} \\
(\%)\end{array}$ & $\begin{array}{c}\text { Lipid }^{1} \\
(\%)\end{array}$ & $\begin{array}{c}\text { Hemicellulose }^{1} \\
(\%)\end{array}$ & $\begin{array}{c}\text { Cellulose }^{1} \\
(\%)\end{array}$ & $\begin{array}{c}\text { Lignin }^{1} \\
(\%)\end{array}$ & $\begin{array}{c}\mathrm{CH}_{4} \\
\left(\mathrm{NL} \mathrm{kg}^{-1} \mathrm{VS}\right)\end{array}$ \\
\hline \multirow{18}{*}{$\begin{array}{l}\text { Animal } \\
\text { manure } \\
\text { group }\end{array}$} & \multirow[t]{2}{*}{ Piglet } & Average & 19.40 & 82.88 & 24.73 & 7.89 & 17.88 & 10.47 & 6.88 & 443.55 \\
\hline & & SD & $(0.70)$ & $(0.18)$ & $(0.79)$ & $(0.40)$ & (1.11) & $(0.62)$ & $(0.64)$ & (13.68) \\
\hline & \multirow[t]{2}{*}{ Sow } & Average & 37.20 & 75.83 & 14.86 & 2.10 & 15.52 & 12.86 & 16.19 & 177.73 \\
\hline & & SD & (1.11) & $(0.19)$ & $(0.59)$ & $(0.12)$ & $(0.46)$ & $(0.66)$ & $(0.34)$ & $(9.32)$ \\
\hline & \multirow[t]{2}{*}{ Cow } & Average & 10.94 & 73.01 & 7.55 & 3.63 & 23.26 & 17.51 & 10.41 & 222.08 \\
\hline & & SD & $(0.94)$ & $(0.91)$ & $(0.41)$ & $(0.39)$ & $(0.76)$ & $(0.47)$ & $(0.90)$ & (1.11) \\
\hline & \multirow[t]{2}{*}{ Buffalo } & Average & 18.16 & 64.42 & 8.79 & 2.16 & 21.54 & 19.84 & 16.24 & 153.01 \\
\hline & & SD & $(0.16)$ & $(0.40)$ & $(0.34)$ & $(0.12)$ & $(0.57)$ & $(0.29)$ & $(0.47)$ & (16.64) \\
\hline & \multirow[t]{2}{*}{ Rabbit } & Average & 32.66 & 39.49 & 8.83 & 2.08 & 19.15 & 15.93 & 14.48 & 172.84 \\
\hline & & SD & $(0.49)$ & $(0.46)$ & $(0.27)$ & $(0.13)$ & $(0.36)$ & $(0.57)$ & $(0.47)$ & (14.36) \\
\hline & \multirow[t]{2}{*}{ Sheep } & Average & 25.39 & 58.42 & 10.18 & 1.26 & 26.12 & 16.67 & 15.21 & 150.55 \\
\hline & & SD & $(0.59)$ & $(0.39)$ & $(0.28)$ & $(0.07)$ & $(0.40)$ & $(0.54)$ & $(0.46)$ & (14.19) \\
\hline & \multirow[t]{2}{*}{ Goat } & Average & 35.26 & 57.01 & 10.18 & 2.45 & 19.51 & 13.33 & 14.58 & 169.86 \\
\hline & & SD & $(0.87)$ & $(0.03)$ & $(0.33)$ & $(0.08)$ & $(0.64)$ & $(0.40)$ & $(0.31)$ & (9.68) \\
\hline & \multirow[t]{2}{*}{ Chicken } & Average & 37.89 & 66.70 & 18.38 & 2.35 & 19.87 & 11.09 & 5.17 & 173.18 \\
\hline & & SD & $(0.33)$ & $(1.01)$ & $(0.38)$ & $(0.11)$ & $(0.63)$ & $(0.25)$ & $(0.18)$ & (26.83) \\
\hline & \multirow[t]{2}{*}{ Dairy cow } & Average & 15.98 & 78.98 & 12.09 & 2.34 & 27.56 & 19.60 & 11.03 & 157.42 \\
\hline & & SD & $(0.19)$ & $(0.06)$ & $(0.15)$ & $(0.10)$ & $(0.40)$ & $(0.73)$ & $(0.44)$ & (7.84) \\
\hline \multirow{6}{*}{$\begin{array}{l}\text { Slaughter } \\
\text { waste }\end{array}$} & \multirow[t]{2}{*}{ Cattle } & Average & 16.97 & 82.56 & 12.45 & 5.04 & 31.11 & 20.39 & 9.64 & 326.60 \\
\hline & & SD & (1.16) & (0.39) & $(0.65)$ & $(0.10)$ & (0.99) & $(0.61)$ & $(0.51)$ & (14.99) \\
\hline & \multirow[t]{2}{*}{ Pig } & Average & 16.20 & 91.70 & 17.49 & 14.38 & 14.18 & 8.97 & 7.95 & 217.45 \\
\hline & & SD & $(0.90)$ & $(0.12)$ & $(0.50)$ & $(0.43)$ & $(0.72)$ & $(0.25)$ & $(0.06)$ & $(3.10)$ \\
\hline & \multirow[t]{2}{*}{ Fish } & Average & 60.00 & 97.47 & 15.00 & 86.01 & 0.52 & 0.25 & 1.08 & 142.23 \\
\hline & & SD & $(0.00)$ & $(0.40)$ & $(0.00)$ & $(0.00)$ & $(0.00)$ & $(0.00)$ & $(0.00)$ & $(27.32)$ \\
\hline \multirow{4}{*}{$\begin{array}{l}\text { Other } \\
\text { waste }\end{array}$} & \multirow[t]{2}{*}{ Household } & Average & 21.81 & 98.63 & 11.18 & 2.42 & 54.21 & 26.11 & 5.01 & 51.40 \\
\hline & & $\mathrm{SD}$ & $(6.43)$ & $(0.08)$ & (1.98) & $(1.27)$ & $(5.95)$ & $(2.74)$ & (1.93) & (9.86) \\
\hline & \multirow[t]{2}{*}{ Shoe water } & Average & 2.78 & 31.94 & 1.7 & 2.2 & 0.00 & 0.00 & 0.00 & 3.6 \\
\hline & & SD & $(0.01)$ & $(0.1)$ & $(0.02)$ & $(0.4)$ & & & & $(0.7)$ \\
\hline \multirow{10}{*}{$\begin{array}{l}\text { Plant } \\
\text { group }\end{array}$} & \multirow{2}{*}{$\begin{array}{l}\text { Water } \\
\text { Spinach }\end{array}$} & Average & 7.13 & 85.73 & 28.45 & 3.69 & 27.25 & 3.51 & 21.36 & 110.61 \\
\hline & & SD & $(0.25)$ & $(0.25)$ & $(0.57)$ & $(0.22)$ & $(0.71)$ & $(0.38)$ & $(0.57)$ & (13.16) \\
\hline & \multirow[t]{2}{*}{ Duckweed } & Average & 7.00 & 72.02 & 21.37 & 3.79 & 13.46 & 8.79 & 9.18 & 340.67 \\
\hline & & SD & $(0.56)$ & (3.71) & $(0.74)$ & $(0.23)$ & (0.59) & $(0.24)$ & $(0.24)$ & (50.47) \\
\hline & \multirow[t]{2}{*}{ Grass } & Average & 16.89 & 88.03 & 9.39 & 1.52 & 31.18 & 27.87 & 6.35 & 220.53 \\
\hline & & SD & $(0.44)$ & $(0.41)$ & $(0.35)$ & $(0.02)$ & $(0.20)$ & (0.19) & $(0.06)$ & (30.91) \\
\hline & \multirow{2}{*}{$\begin{array}{l}\text { Cassava } \\
\text { Residue }\end{array}$} & Average & 18.63 & 98.07 & 2.90 & 0.80 & 10.65 & 8.87 & 16.33 & 33.46 \\
\hline & & SD & $(0.40)$ & $(0.03)$ & $(0.20)$ & $(0.06)$ & $(0.45)$ & $(0.12)$ & $(0.59)$ & (3.39) \\
\hline & \multirow[t]{2}{*}{ Inoculum } & Average & 11.70 & 58.72 & 7.16 & 0.82 & 12.67 & 15.74 & 19.63 & 51.17 \\
\hline & & SD & $(0.02)$ & $(0.33)$ & (0.04) & $(0.03)$ & $(0.15)$ & $(0.26)$ & $(0.07)$ & $(0.64)$ \\
\hline
\end{tabular}


and Thailand (Jørgensen et al., 2013). Plant protein contents were quite high for water spinach and duckweed at $28.4 \%$ and $21.3 \%$, respectively, compared to the animal manures. These plants are frequently used as a source of pig feed on a household scale.

Lignin content has been proven to be a good predictor of methane potential (Triolo et al., 2011). This study has shown that lignin concentrations in ruminant manures from buffaloes, cows, sheep and goats were higher than in piglet or chicken manure, although the lignin concentration in sow manure was quite high at $16.2 \%$ since the main feed ingredient for sows in Vietnam is plant residues. For the plants, water spinach had a higher lignin concentration than duckweed and grass.

\section{Biochemical methane production potential}

The highest BMP in this study was from piglet manure at $443.6 \mathrm{NL} \mathrm{CH}_{4}\left(\mathrm{~kg} \mathrm{VS}^{-1}\right)$, followed by cow, sow, chicken, rabbit, buffalo and sheep manures at 222, 177.7, 173, 172.8, 153, and 150.5 $\mathrm{NL} \mathrm{CH}_{4}\left(\mathrm{~kg} \mathrm{VS}^{-1}\right)$, respectively (Figure 1). The BMP of dairy cow, buffalo and other cattle measured in this study is higher than those given for the manure categories in the IPCC guideline (IPCC, 2006), which are $130 \mathrm{NL} \mathrm{CH}_{4}\left(\mathrm{~kg} \mathrm{VS}^{-1}\right)$ for dairy cow manure, $100 \mathrm{NL} \mathrm{CH}_{4}$ $\left(\mathrm{kg} \mathrm{VS}^{-1}\right)$ for buffalo and $100 \mathrm{NL} \mathrm{CH}_{4}\left(\mathrm{~kg} \mathrm{VS}^{-1}\right)$ for other cattle manure. The intergovernmental panel on climate change values of BMP for swine manure are 290 and for rabbit manure $320 \mathrm{NL} \mathrm{CH}_{4}\left(\mathrm{~kg} \mathrm{VS}^{-1}\right)$, which is higher than BMP measured in this study. The difference is probably due to differences in composition of diet given as feed to the livestock and indicates that it is necessary to determine BMP value of Vietnamese animal manure categories.

At $173 \mathrm{NL} \mathrm{CH}_{4}\left(\mathrm{~kg} \mathrm{VS}^{-1}\right)$, the BMP of chicken manure was relatively low, with the $\mathrm{CH}_{4}$ concentration ranging from $31 \%$ to $45 \%$ in the first ten days of incubation, thereafter increasing to $60 \%$ to $70 \%$. However, this does not differ greatly from the study by Abouelenien et al. (2010) where $\mathrm{CH}_{4}$ yield was $195 \mathrm{NL} \mathrm{CH}_{4}\left(\mathrm{~kg} \mathrm{VS}^{-1}\right)$. The high nitrogen concentration $\left(11,130 \mathrm{mg} \mathrm{L}^{-1}\right)$ in the chicken manure is considered to be the main inhibiting factor. The two forms of inorganic ammonia nitrogen-ammonium $\left(\mathrm{NH}_{4}^{+}\right)$and free ammonia $\left(\mathrm{FAN}, \mathrm{NH}_{3}\right)$ - can directly or indirectly cause inhibition in an anaerobic digestion process in which FAN is the more powerful inhibitor (Yenigün and Demirel, 2013). A total ammoniacal nitrogen (TAN) concentration of 1,700 to $1,800 \mathrm{mg} \mathrm{L}^{-1}$ has been shown to cause reaction failure, and a TAN concentration of $150 \mathrm{mg}$ $\mathrm{L}^{-1}$ may inhibit anaerobic digestion (Yenigün and Demirel, 2013).

Some attempts are made to avoid accumulation of FAN during methane fermentation, such as dilution with water from $10 \%$ to $11.5 \%$ total solid or co-digestion with other livestock manures such as cattle manure or with digestate sludge (Bujoczek et al., 2000). However, these methods lead to increased amounts of waste and hence increase storage and transportation costs. In recent research the focus has been on removing FAN from chicken manure by pretreatment using physicochemical or biological methods such as pH adjustment (Abouelenien et al., 2010).

This study showed that cattle and pig slaughter waste could be very useful for biogas production, with BMPs of 311.8 and 206.5 $\mathrm{NL} \mathrm{CH}_{4}\left(\mathrm{~kg} \mathrm{VS}^{-1}\right)$, respectively. This result is within the range of the 200 to $600 \mathrm{NL} \mathrm{CH}_{4}\left(\mathrm{~kg} \mathrm{VS}^{-1}\right)$ for slaughterhouse wastes found in a previous study by Hejnfelt and Angelidaki (2009). Slaughterhouse contents in other studies included all the internal organs such as kidneys, livers, intestines and stomachs, but generally Vietnamese slaughterhouses mainly provide the intestines, stomach etc. The BMP from fish waste in this study was $142.2 \mathrm{NL} \mathrm{CH}_{4}$ $\left(\mathrm{kg} \mathrm{VS}^{-1}\right)$. According to fish market research (Energy Fish

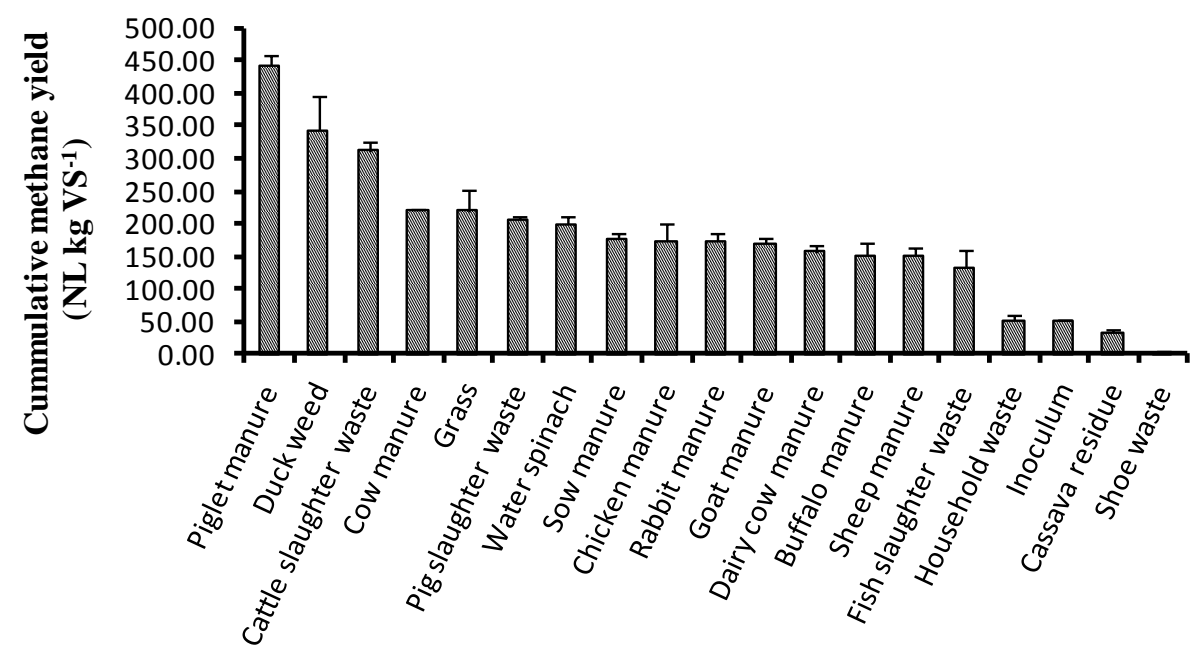

Figure 1. Summary of methane production potential from the BMP test of substrates. Error bars indicate the standard deviation for each substrate. BMP, biochemical methane potential. 
Market, 2011) Vietnam is the third largest fish-producing country in the world and much waste fish biomass is available in the country. Fish oil from internal organ waste processing can be used for biodiesel and waste water from fish-processing can also be a potential source of biogas production. The BMP from household waste was also very low at $51.40 \mathrm{NL} \mathrm{CH}_{4}\left(\mathrm{~kg} \mathrm{VS}^{-1}\right)$ with a $\mathrm{CH}_{4}$ concentration of around $30 \%$ to $40 \%$ (Figure 1). Although the household waste was sorted out, it contained substances that inhibited the biogas process. The BMP from shoe waste was very low at $3.6 \mathrm{NL} \mathrm{CH}_{4}\left(\mathrm{~kg} \mathrm{VS}^{-1}\right)$ with a $\mathrm{CH}_{4}$ concentration of less than $5 \%$. This waste was therefore not a suitable substrate for biogas production. The reason is that shoe leather waste contains heavy metals (copper, cobalt, or zinc) from shoe processing, which inhibit the methanogens (Herva et al., 2011). Sewage from the shoe-making industry is a source of environmental pollution. The materials used in leather shoemaking are mainly buffalo and cow hides. The main wastewater treatment method in shoe-making companies is currently anaerobic sedimentation lakes that frequently overflow and pollute the environment, causing odors and damage to crop production. Most neighbours to leather shoe-making companies complain about the pollution they cause (Ha Thuy, 2013). It was therefore examined whether this wastewater could be used for biogas production.

The cumulative $\mathrm{CH}_{4}$ yield for all biomasses in this study is shown in Figure 1. Figure 2a shows a prolonged lag phase in the cumulative $\mathrm{CH}_{4}$ yield for both pig and fish slaughter waste. Pig slaughter waste had a lag phase of 37 days, but methane concentration was quite stable at $55 \%$ to $70 \%$ during the entire period of the experiment. The lag phase for fish slaughter waste occurred from day 7 and then lasted for 40 days, but the $\mathrm{CH}_{4}$ concentration was low in weeks 3 and 4 at $41 \%$ to $42 \%$ and stabilised from week 5 with a $\mathrm{CH}_{4}$ concentration of $60 \%$ to $70 \%$.

A lag is a common problem when substrates have high lipid and protein concentrations (Palatsi et al., 2011) such as fish. The degradation of lipids will produce intermediate products, one of which is long-chain fatty acids (LCFA). This product has been proven to inhibit the transfer of substrates and metabolites through the microbial cell wall. A study by Hejnfelt and Angelidaki (2009) indicated that LCFA and ammonia inhibitions will occur in biogas processes when their concentrations are higher than $5 \mathrm{~g} \mathrm{~L}^{-1}$ of lipids and $7 \mathrm{~g} \mathrm{~L}^{-1}$ of nitrogen. Consequently, LCFA inhibition usually produces an initial delay in $\mathrm{CH}_{4}$ formation or a long lag phase before complete substrate degradation (Hejnfelt and Angelidaki, 2009; Palatsi et al., 2011). The LCFA inhibition could be avoided by pretreatments such as alkali hydrolysis $(\mathrm{NaOH})$, sterilization at $133^{\circ} \mathrm{C}$, pasteurization at $70^{\circ} \mathrm{C}$ or co-digestion with other biomasses with lower lipid and protein concentrations. No lag phase was noticed for cattle slaughter waste.
Despite problems with inhibition, biogas production from slaughterhouses has a great potential due to the rich nutrient contents. Slaughterhouses in Vietnam are often the cause of extremely heavy environmental pollution. Some large abattoirs located in cities and controlled by the government have waste treatment systems, but most small and medium-size slaughterhouses located in suburban areas release untreated slaughterhouse waste and effluent directly into sewers, channels, lakes and ponds. This not only causes nutrient enrichment, but also has an impact on hygiene and produces odours. The environmental problems can be alleviated through biogas treatment and recycling the treated digestate (Cuetos et al., 2010).

The BMP of water spinach was high with a methane yield of $343.8 \mathrm{NL} \mathrm{CH}_{4}\left(\mathrm{~kg} \mathrm{VS}^{-1}\right)$, followed by $220.5 \mathrm{NL}$ $\mathrm{CH}_{4} /\left(\mathrm{kg} \mathrm{VS}^{-1}\right)$ for duckweed and 199.5 $\mathrm{NL} \mathrm{CH}_{4} /\left(\mathrm{kg} \mathrm{VS}^{-1}\right)$ for grass (Figure 2c). Since these plants produce a high biomass yield under Vietnamese conditions, they could provide considerable biogas energy for local communities. Cassava production has developed rapidly in Vietnam recently with the cassava yield growing from 1.99 million tonnes in 2000 to 9.45 million tonnes in 2009 (FAO stat, 2010). According to estimates by Nguyen et al. (2004), in Vietnam, 1 tonne of fresh cassava produces 0.3 tonne residues. With an estimate of three million tonnes of cassava residue in 2009 , this could be a large potential feed source for biogas production. However, the BMP from cassava residue was low at $33.5 \mathrm{NL} \mathrm{CH}_{4}\left(\mathrm{~kg} \mathrm{VS}^{-1}\right)$ and its $\mathrm{CH}_{4}$ concentration was very low, varying from $24 \%$ to $36 \%$. The reason for this is that cassava residues contain hydrogen cyanide ( $\mathrm{HCN})$, an acid that inhibits the methanogens (Paixão et al., 2000). Biological pre-treatment is considered a simple and cheap method for reducing $\mathrm{HCN}$ by adding microorganism strains that have the ability to reduce the cyanide concentration (Bacilli bacterium) and also other bacterial strains that are able to enhance the degradation of cellulose complexes (Zhang et al., 2011).

\section{Developing equations to predict biochemical methane potential}

Equations to predict BMP are shown in Table 3. Biogas production is related to the chemical composition of the substrate. Low concentrations of organic matter such as lipids and protein will lead to a low biogas production. However, very high organic matter concentrations in substrates will have a negative effect on biogas production, causing foaming and inhibition if not co-fermented with biomasses low in protein and lipids (Kougias et al., 2013). Therefore six wastes shown to inhibit $\mathrm{CH}_{4}$ production were excluded from the calculation (cassava residue, shoe waste, chicken manure, fish slaughter waste, pig slaughter waste and household waste). Thirteen wastes that did not inhibit production were included to develop the model (piglet 

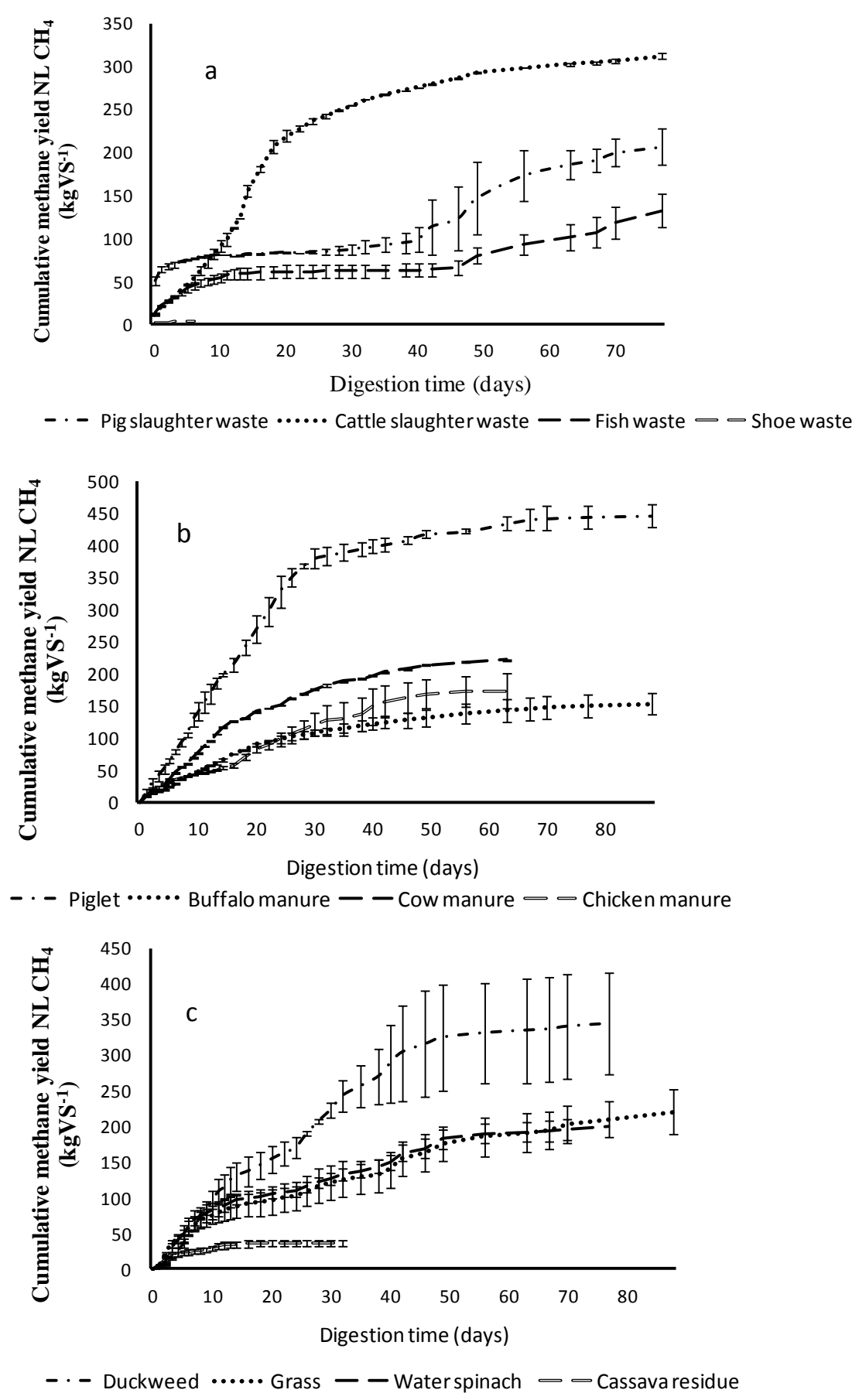

Figure 2. Cumulative methane production of each sample measured. (a) Cumulative methane production curves from the slaughter waste group; (b) cumulative methane production curves from the animal manure group; (c) cumulative methane production curves from the plant group. Error bars represent standard deviations.

manure, sow manure, cow manure, buffalo manure, rabbit manure, sheep manure, goat manure, dairy cow manure, cattle slaughter waste, water spinach, duckweed, grass, and inoculum).

A clear relationship between lipid content of the biomass and BMP can be seen and lipid content is the most important factor for BMP compared with other components
( $\mathrm{p}=0.003$ ). The lipid content of the manure could explain $67.9 \%$ of the variation in BMP, and the lipid content of the manure and plant residue could explain $59.9 \%$ of the variation in BMP. However, in biogas technology every component in the substrates affects biogas production, as will their interaction. Therefore the correlation between the components contributing to biogas production was analysed 
Table 3. Equation to predict BMP for animal manures and plant residues

\begin{tabular}{|c|c|c|c|c|}
\hline Substrates & Variables $^{1}$ & Equations for $\mathrm{BMP}^{2}$ & $\mathrm{R}^{2}$ & $\mathrm{p}$ value \\
\hline \multirow[t]{4}{*}{ Manure group } & Lipid & $57.9+35 \times$ lipid & 67.9 & $<0.005$ \\
\hline & Lipid, lignin & 186+30.6×lipid-5.13×lignin & 95.8 & $<0.001$ \\
\hline & Lipid, lignin, DM & $167+30.1 \times$ lipid $-5.43 \times$ lignin $+1.15 \times \mathrm{DM}$ & 96.6 & $<0.001$ \\
\hline & Lipid, lignin, cellulose & $201+31.5 \times$ lipid $-3.85 \times$ lignin $-1.88 \times$ cellulose & 96.6 & $<0.001$ \\
\hline \multirow{3}{*}{$\begin{array}{l}\text { Combined manure } \\
\text { and plant group }\end{array}$} & Lipid & 78.4+33.4×lipid & 59.9 & $<0.005$ \\
\hline & Lipid, lignin & 198+31.2×lipid-5.51×lignin & 94.3 & $<0.001$ \\
\hline & Lipid, lignin, protein & $192+26.1 \times$ lipid $-5.97 \times$ lignin $+1.88 \times$ protein & 95.5 & $<0.001$ \\
\hline
\end{tabular}

BMP, biochemical methane potential; DM, dry matter; VS, volatile solid; NL, normal litter.

${ }^{1}$ Lipid, lignin, protein, cellulose: $\%$ in VS. ${ }^{2} \mathrm{NL} \mathrm{CH}_{4}\left(\mathrm{~kg} \mathrm{VS}^{-1}\right)$.

by using 'best subset' regression analysis (Table 3). It was found that lipid, lignin, protein, and cellulose contents were the main chemical components of the substrates contributing to the variation in BMP. These contents could explain $96.6 \%$ and $95.5 \%$, respectively, of the variation in BMP of the manure and of manure and plant residues (Figure 3). In the equation for BMP in the manure group, two equations had the same $\mathrm{R}^{2}$ value $(96.6 \%)$. The first equation was explained by lipid, lignin and DM components and the second equation by lipid, lignin and cellulose components.

\section{Biogas production-dome digesters}

The $\mathrm{CH}_{4}$ production of pig farms with 17 fattening pigs (Figure 4) was calculated based on the BMP measurement and extended Hashimoto model (Equations 1 and 2). Sapa

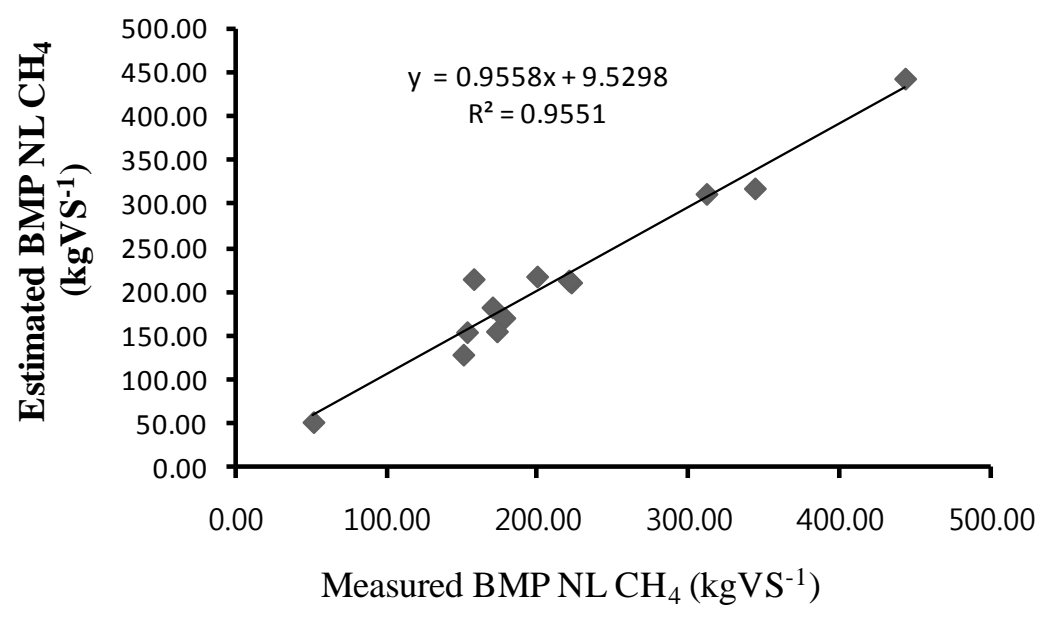

Figure 3. Scatter diagram showing regression of predicted vs measured BMP from the combined model with a correlation coefficient of 95.5\% (The 13 samples that didn't inhibit the gas production were used in the comparison). BMP, biochemical methane potential.

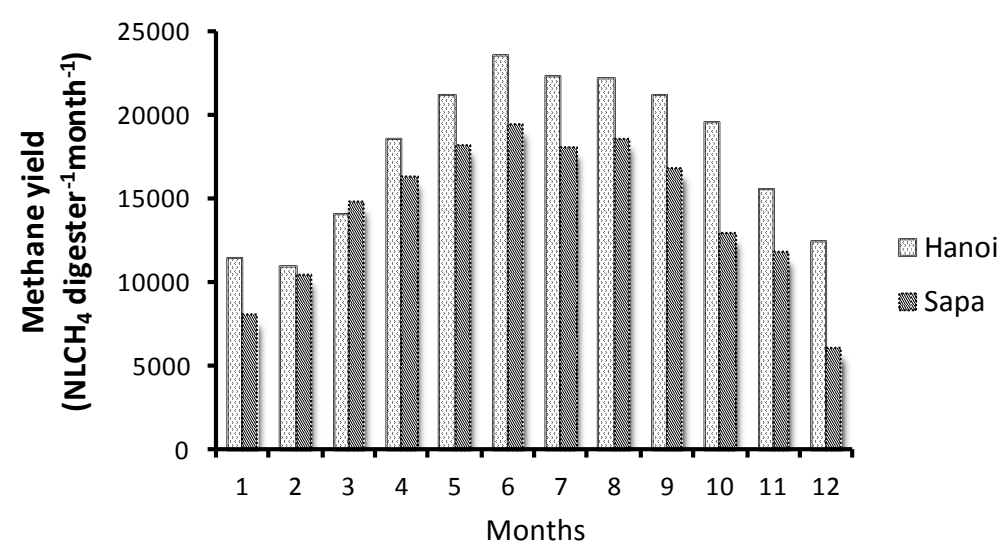

Figure 4. $\mathrm{CH}_{4}$ yield for a digester with 17 fattening pigs, 38.3 days HRT in lowland and highland area $\left(\mathrm{NLCH}_{4}\right.$ per digester per month). HRT, hydraulic retention time; NL, normal litter. 
and Hanoi cities represented the highland and lowland areas of northern Vietnam. Sapa in the highland region has temperatures lower than other cities in Vietnam, and Hanoi is representative of the climate in northern Vietnam. Figure 4 reveals the naturally lower biogas production in the colder winter months from November to January. In December, biogas production in Hanoi is around $12.46 \mathrm{~m}^{3}\left(0.41 \mathrm{~m}^{3}\right.$ per day) and in Sapa $6.04 \mathrm{~m}^{3}\left(0.20 \mathrm{~m}^{3}\right.$ per day $)$. In the summer months of June, July, and August, biogas production is higher and in Hanoi is about $23.58 \mathrm{~m}^{3}\left(0.78 \mathrm{~m}^{3}\right.$ per day $)$ and in Sapa $19.43 \mathrm{~m}^{3}\left(0.65 \mathrm{~m}^{3}\right.$ per day $)$ per digester. According to studies by $\mathrm{Vu}$ et al. (2012), the biogas volume needed for a typical farming household of six people is 0.8 to $1 \mathrm{~m}^{3}$ per day. If the $\mathrm{CH}_{4}$ concentration in biogas is $65 \%$, the amount of $\mathrm{CH}_{4}$ is about 0.52 to $0.65 \mathrm{~m}^{3}$ per day. So in December in both Hanoi and Sapa, the $\mathrm{CH}_{4}$ produced is inadequate to meet household needs and in the summertime the methane produced exceeds household needs. If farmers were to have this information, they could adjust the feeding of their digester to increase gas production in winter and reduce it in summer.

\section{CONCLUSION}

Piglet manure produced the highest methane yield at $443 \mathrm{NL} \mathrm{CH}_{4}\left(\mathrm{~kg} \mathrm{VS}^{-1}\right)$, followed by cow, rabbit, goat and sheep manure at, respectively, 222, 172, 169, and $150 \mathrm{NL}$ $\mathrm{CH}_{4}\left(\mathrm{~kg} \mathrm{VS}^{-1}\right)$. Methane production from duckweed was higher than that from grass and water spinach at 340.6, 220, and $110.6 \mathrm{NL} \mathrm{CH}_{4}\left(\mathrm{~kg} \mathrm{VS}^{-1}\right)$, respectively. Inhibitors were found in the BMP experiment in pig slaughter waste, fish waste, chicken manure, cassava residues, shoe-making waste and household waste. An equation was developed to predict methane potential from the chemical compositions of biomass with an $\mathrm{R}^{2}$ of 0.96 for the animal manure biomass group and 0.95 for the combined animal and plant biomass group. Lipid, lignin, protein, and cellulose contents in biomass were the best predictors of BMP value. From the equation developed, a case study was used with Sapa and Hanoi representing highland and lowland Vietnam to calculate the monthly/daily production of methane in a $7 \mathrm{~m}^{3}$ volume digester with 17 fattening pigs and 38 days retention time. The production was found to be insufficient for winter requirements but to exceed summer requirements for both Sapa and Hanoi.

\section{ACKNOWLEDGMENTS}

The present study was supported by grants from the SUSANE II project - DANIDA, Denmark. The authors would like to express their sincere thanks to the Central Laboratory of the Faculty of Animal Science and Aquaculture, Hanoi University of Agriculture, where the study was conducted.

\section{REFERENCES}

Abouelenien, F., W. Fujiwara, Y. Namba, M. Kosseva, N. Nishio, and Y. Nakashimada. 2010. Improved methane fermentation of chicken manure via ammonia removal by biogas recycle. Bioresour. Technol. 101:6368-6373.

Amon, T., B. Amon, V. Kryvoruchko, W. Zollitsch, K. Mayer, and L. Gruber. 2007. Biogas production from maize and dairy cattle manure-influence of biomass composition on the methane yield. Agric. Ecosyst. Environ. 118:173-182.

Ankom technology protocol. http://www.ankom.com/procedures. aspx. Accessed March 1, 2014.

APHA. 2005. Standard Methods for the Examination of Water and Wastewater, 21st ed. American Public Health Association, Washington, DC, USA.

Bruun, S., L. S. Jensen, V. Vu Thi Khanh, and S. G. Sommer. 2014 Rural household biogas digesters-An option for global warming mitigation and a potential climate bombs (Feature article). Renew. Sust. Energy Rev. 33:736-741.

Bujoczek, G., J. A. Oleszkiewicz, R. R. Sparling, and S. Cenkowski. 2000. High solid anaerobic digestion of chicken manure. J. Agric. Eng. Res. 76:51-60.

Cu, T. T. T., H. C. Pham, T. H. Le, V. C. Nguyen, X. A. Le, X. T. Nguyen, and S. G. Sommer. 2012. Manure management practices on biogas and non-biogas pig farms in developing countries - using livestock farms in Vietnam as an example. J. Clean. Prod. 27:64-71.

Chen, Y. R. and A. G. Hashimoto. 1978. Kinetics of methane fermentation. In: Proceedings of Symposium on Biotechnology in Energy Production and Conservation (Ed. C. D. Scott). Wiley, New York, USA. p. 269.

Cuetos, M. J., X. Gómez, M. Otero, and A. Morán. 2010. Anaerobic digestion and co-digestion of slaughterhouse waste (SHW): Influence of heat and pressure pre-treatment in biogas yield. Waste Manag. 30:1780-1789.

FAO Stat. 2010. http://faostat.fao.org/DesktopDefault.aspx? PageID=339\&lang=en. Accessed March 1, 2014.

Energy fish market. Enerfish Consortium. 2011. Market Study. http://www.enerfish.eu/uploaded/results/results_9.pdf. Accessed May 1, 2014.

Goering, H. K. and P. J. Van Soest. 1970. Forage Fiber Analysis (Apparatus, Reagents, Procedures and Some Applications). Agriculture Handbook No. 379. Agriculture Research Service, United States Department of Agriculture, Washington, DC, USA.

Gunaseelan, V. N. 1997. Anaerobic digestion of biomass for methane production: A review. Biomass Bioenergy 13:83-114.

Hashimoto, A. G., Y. R. Chen, and V. H. Varel. 1981. Theoretical aspects of methane production: State-of-the-art. In Livestock Wastes: A Renewable Resource. ASAE. St. Joseph. MI, USA. pp. 86-91.

Hejnfelt, A. and I. Angelidaki. 2009. Anaerobic digestion of slaughterhouse by-products. Biomass Bioenergy 33:10461054.

Herva, M, A. Álvarez, and E. Roca. 2011. Sustainable and safe design of footwear integrating ecological footprint and risk criteria. J. Hazard. Mater. 192:1876-1881. 
IPCC. 2006. IPCC Guidelines for National Greenhouse Gas Inventories. http://www.ipcc-nggip.iges.or.jp/public/2006gl/ index.html. Accessed July 20, 2014.

Institute of Energy. 2010. The Power Master Plan VII. 2010. http://www.nti.org/media/pdfs/VietnamPowerDevelopmentPla n2030.pdf?_=1333146022. Accessed April 15, 2014.

Jørgensen, H., T. Prapaspongsa, V. T. K. Vu, and H. D. Poulsen. 2013. Models to quantify excretion of dry matter, nitrogen, phosphorus and carbon in growing pigs fed regional diets. J. Anim. Sci. Biotechnol. 4:42.

Khanh Toan, P., N. Minh Bao, and N. Ha Dieu. 2011. Energy supply, demand, and policy in Viet Nam, with future projections. Energy Policy 39:6814-6826.

Kougias, P. G., K. Boe, and I. Angelidaki. 2013. Effect of organic loading rate and feedstock composition on foaming in manurebased biogas reactors. Bioresour. Technol. 144:1-7.

Le, Q. S., T. N. Nguyen, and B. H. Bui. 2013. Using forecasting models to calculate the potential of biogas from vegetable waste for Vietnamese conditions. J. Energy Sci. 1:17-24.

Leinoen, A. and N. D. Cuong. 2013. Development of Biomass Fuel Chain in Vietnam. VTT Technology 134. Julkaisija Utgivare Publisher. Finland http://www.vtt.fi/inf/pdf/ technology/2013/T134.pdf Accessed October 1, 2014.

Møller, H. B., S. G. Sommer, and B. K. Ahring. 2004. Methane productivity of manure straw and solid fractions of manure. Biomass Bioenergy 26:485-495.

Nijaguna, B. T. 2002. Biogas Technology. New Age International (P) Ltd., New Delhi, India.

Nguyen, Truong Le and Cu, Tran Quang. 2004. Potential of Distributed Power Generation from Biomass Residues in Vietnam - Status and Prospect. Proceedings of Electricity Supply Industry in Transition and Prospect for Asia. January 14-16, 2004; Hanoi, Vietnam. 28-39.

Paixão, M. A., C. R. G. Tavares, R. Bergamasco, A. L. E. Bonifácio, and R. T. Costa. 2000. Anaerobic digestion from residue of industrial cassava industrialization with acidogenic and methanogenic physical separation phases. Appl. Biochem. Biotechnol. 84-86:809-819.

Palatsi, J., M. Vinas, M. Guivernau, B. Fernandez, and X. Flotats. 2011. Anaerobic digestion of slaughterhouse waste: main process limitations and microbial community interactions. Bioresour. Technol. 102:2219-27.
Perrigault, T., V. Weatherford, J. Martí-Herrero, and D. Poggio. 2012. Towards thermal design optimization of tubular digesters in cold climates: A heat transfer model. Bioresour. Technol. 124:259-268.

Pham, C. H., J. M. Triolo, and S. G. Sommer. 2014. Predicting methane production in simple and unheated biogas digesters at low temperatures. Appl. Energy 136:1-6.

Rennuit, C. and S. G. Sommer. 2013. Decision support for the construction of farm-scale biogas digesters in developing countries with cold seasons. Energies 6:5314-5332.

Sommer, S. G., N. J. Hutchings, and O. T. Carton. 2001. Ammonia losses field applied animal manure. DIAS report. No 60, Plant production. Ministry of Food, Agriculture and Fisheries. Danish Institute of Agriculture Sciences, Aarhus, Danmark.

Thuy Duong. 2013. By-products from agriculture - Multibenefits. http://bhxhdaknong.gov.vn/index.php/vi/news/Tin-DakNong/Tan-dung-phu-pham-tu-nong-nghiep-Loi-ich-nhieu-mat134/. Accessed March 12, 2014.

Triolo, J. M., S. G. Sommer, H. B. Moller, M. R. Weisbjerg, and X. Y. Jiang. 2011. A new algorithm to characterize biodegradability of biomass during anaerobic digestion: influence of lignin concentration on methane production potential. Bioresour. Technol. 102:9395-9402.

Van Soest, P. J. 1963. Use of detergents in the analysis of fibrous feeds. II. A rapid method for the determination of fiber and lignin. J. Assoc. Offic. Agric. Chem. 46:829-835.

Vu, Q. D., T. M. Tran, P. D. Nguyen, C. C. Vu, V. T. K. Vu, and L. S. Jensen. 2012. Effect of biogas technology on nutrient flows for small- and medium-scale pig farms in Vietnam. Nutr. Cycl. Agroecosyst. 94:1-13.

Weather forecast website. http://www.accuweather.com/vi/vn/ hanoi/353412/month/353412?monyr=1/01/2013. Accessed March 18, 2014

Yenigün, O. and B. Demirel. 2013. Ammonia inhibition in anaerobic digestion: A review. Process Biochem. 48:901-911.

Zhang, Q., J. He, M. Tian, Z. Mao, L. Tang, J. Zhang, and H. Zhang. 2011. Enhancement of methane production from cassava residues by biological pretreatment using a constructed microbial consortium. Bioresource Technol. 102:8899-8906. 